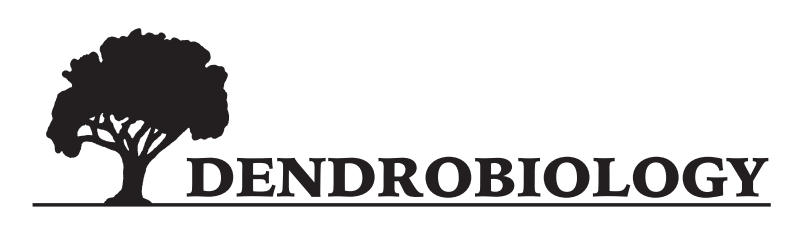

2015, vol. 74, 69-76

http://dx.doi.org/10.12657/denbio.074.007

Terezia Salaj, Radoslava Matusova, Jan Salaj

\title{
Conifer somatic embryogenesis - an efficient plant regeneration system for theoretical studies and mass propagation
}

\author{
Received: 17 October 2014; Accepted: 23 March 215
}

\begin{abstract}
Since the first report of somatic embryogenesis in Norway spruce in 1985, the in vitro process has been initiated for a number of conifer species belonging to different genera. The process of somatic embryogenesis involves initiation, proliferation, maturation and plantlets (emblings) regeneration. The initiation of somatic embryogenesis is restricted mostly to juvenile explants, although recently explants taken from adult trees produced embryogenic tissues. The successful initiation, maturation and emblings regeneration are affected by factors as developmental stage of primary explants, genotype, plant growth regulators content in the culture medium, light conditions. Optimisation of mentioned factors resulted in regeneration of emblings capable of growing after transfer to soil.
\end{abstract}

Additional key words: in vitro, plant biotechnology, plant growth regulators (PGRs)

Address: T. Salaj, R. Matusova, J. Salaj, Institute of Plant Genetics and Biotechnology, Slovak Academy of Sciences, Akademická 2, P.O.Box 39A, 95007 Nitra, Slovak Republic, e-mail: terezia.salaj@savba.sk

\section{Introduction}

Somatic embryogenesis (SE) is an in vitro process of embryo differentiation without sexual fusion of gametes from somatic cells of a plant body. Owing to the origin, the differentiated structures are called somatic embryos and, in morphology as well as internal organisation of tissues, they resemble their counterparts in seeds resulted from gamete fusion. In appropriate conditions the differentiated structures develop and their development results in complete plant formation.

The process was first described for carrot in 1958 and later for numerous angiosperm species. For conifers, SE was first reported for Norway spruce (Hakman et al. 1985; Chalupa 1985) and has since been achieved for other conifer species belonging to genera Abies, Picea, Pinus, Larix, Pseudotsuga and Taxus. It is worth to mention that in suspension cultures of $P i$ nus banksiana, Durzan and Chalupa (1976) observed cell aggregates, long vacuolised cells resembling the suspensor cells as well as polarised structures that did not develop further into bipolar structures described later as somatic embryos and no plantlet regeneration occurred. For conifers, the process of SE represents an excellent plant regeneration system available for the theoretical study of early plant development and is convenient for large-scale trees vegetative propagation. Conifer SE as a plant regeneration system plays also an important role in biotechnological approaches as genetic transformation and cryopreservation. 


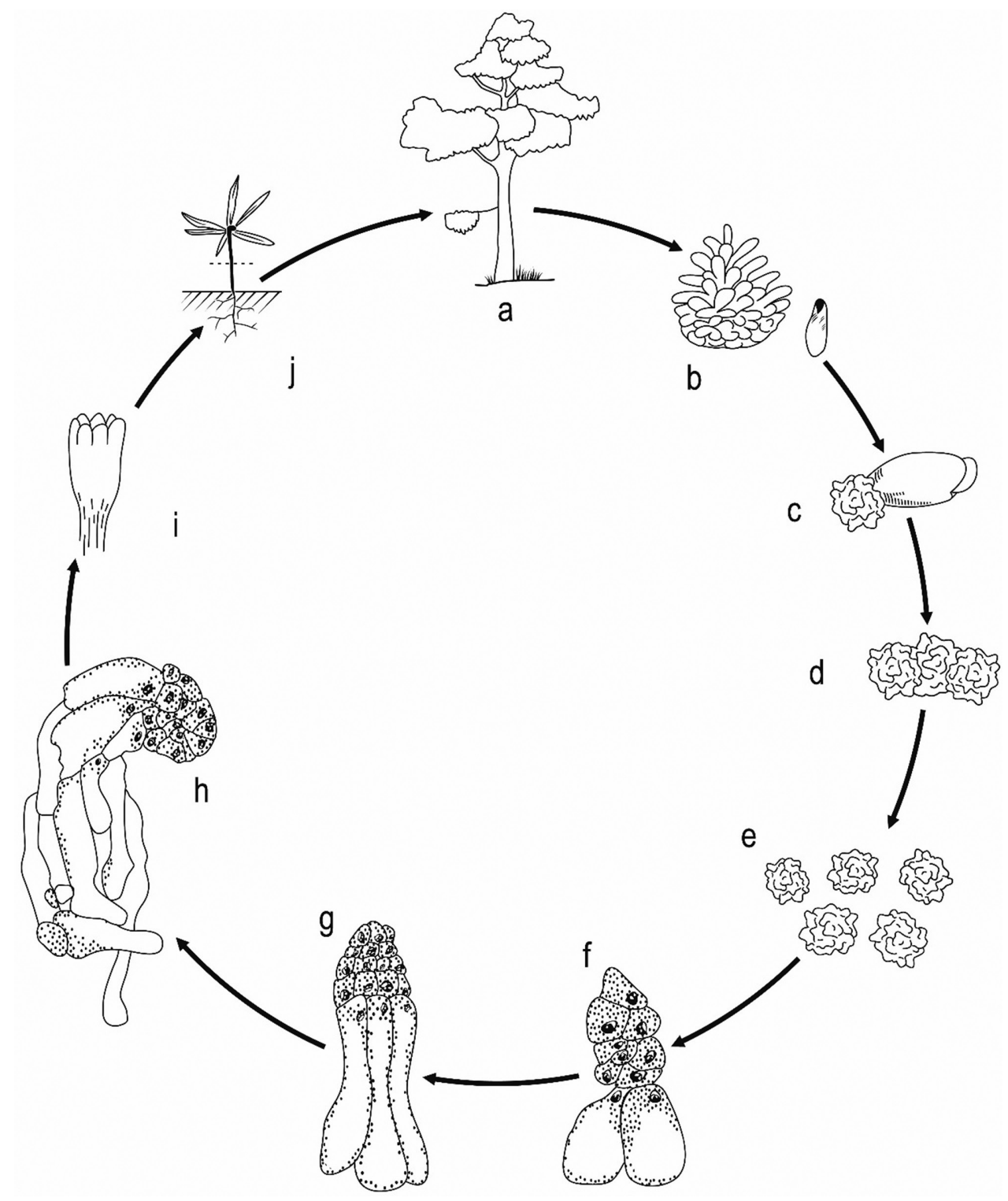

Fig. 1. Embling (somatic seedling) regeneration via somatic embryogenesis (an example of Pinus nigra): from an adult tree (a) green cones are collected (b) and the excised megagametophytes of immature seeds as explants are placed on the culture medium. Approximately after 12-15 days of cultivation embryogenic tissue is produced on explants (c). Reaching $0.5-1 \mathrm{~cm}$ in size (d) the tissue is separated from megagametophyte explants and divided into several pieces (e) and cultivated. Microscopic examination reveals bipolar strucures - somatic embryos in the tissue (f, g, h). In appropriate conditions the bipolar structures develop into mature somatic embryos with apparent cotyledons (i). The mature somatic embryos give rise to small plantlets - emblings capable of growth in soil (j). The emblings have the potential to grow and develop into adult tree (a). With permission from Salaj and Ostrolucká (2010)

The in vitro process of SE can be divided into several steps as a) initiation, b) proliferation, c) maturation, d) plantlet regeneration (Fig. 1).

\section{Initiation of somatic embryogenesis}

The effect of plant growth regulators - plant growth regulators play key role in the initiation of somatic embryogenesis. Different concentration and combination of auxins and cytokinins were used and these requirements have to be tested for each explant type as well as species. The auxin most frequently used is 2,4-D (dichlorophenoxyacetic acid, a synthetic auxin) and BA (6-benzyladenine) is the most common cytokinin. As a rule concentrations of 2,4-D in culture media are higher in comparison to BA concentrations. Although the most frequently used plant growth regulators are 2,4-D and BA, sometimes BA can be replaced by kinetin and 2,4-D by NAA. For some species solo PGRs (BA, 2,4-D) were efficient to initiate embryogenic tissues (for details see review Tautorus et al. 1991; Attree and 

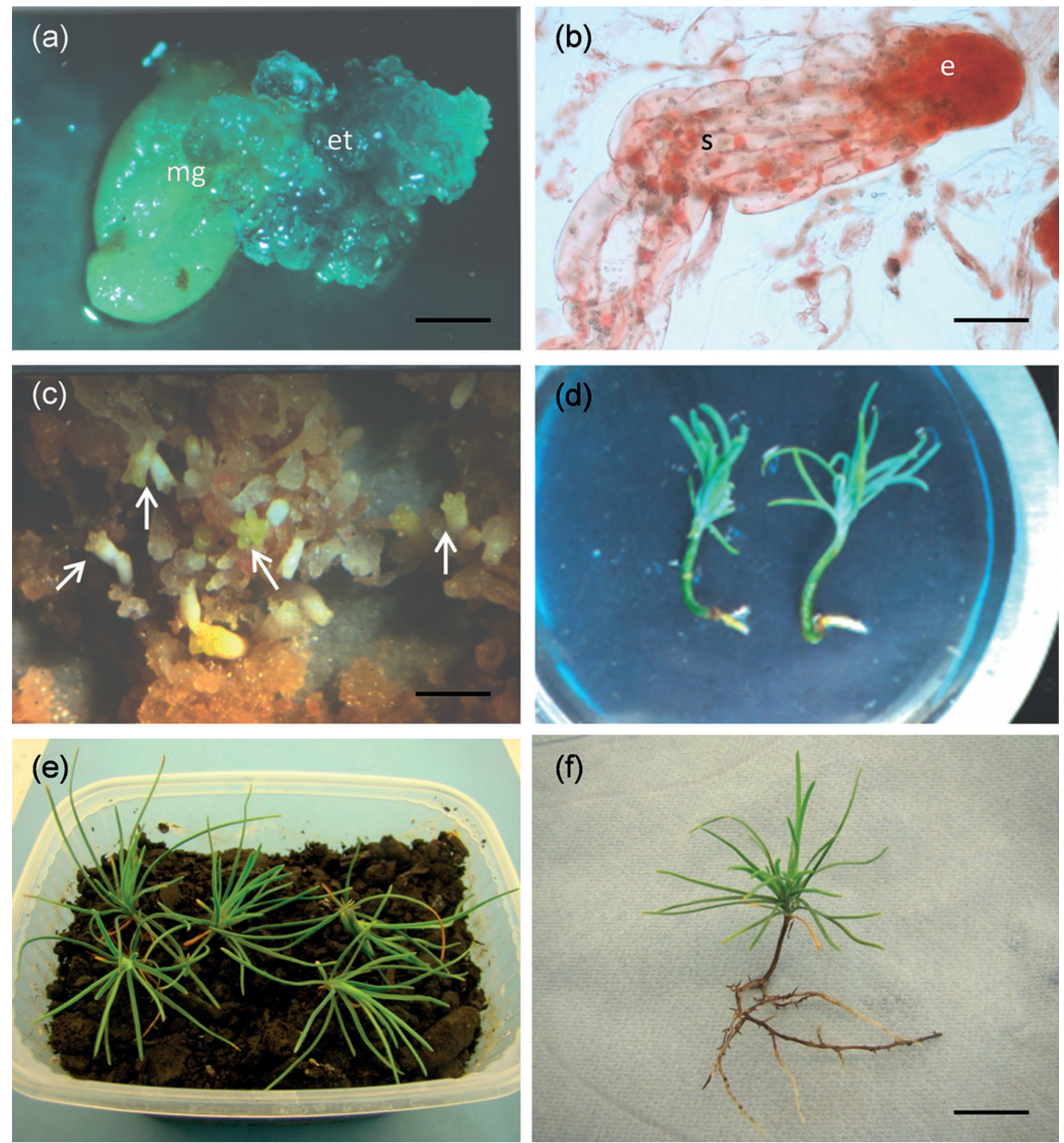

Fig. 2. Developmental sequences in conifer somatic embryogenesis (an example of Pinus nigra): (a) - protruding embryogenic tissue (et) from the megagametophyte explant (mg), (b) - early bipolar somatic embryo at stage 1 (e - embryonal cells, s -suspensor), (c) - cotyledonary somatic embryos (arrows), (d) - emblings, (e) - emblings transferred to soil, (f) - embling growing in the soil for 3 months (a, c, d - with permission from Salaj and Ostrolucká 2010). Bars: (a) $1.2 \mathrm{~mm}$, (b) $-200 \mu \mathrm{m}$, (c) $-5 \mathrm{~mm}$, (f) $-15 \mathrm{~mm}$

Fowke 1993; Klimaszewska and Cyr 2002; Lelu-Walter et al. 2013).

Explants for initiation of somatic embryogenesis Juvenile explants as immature or mature zygotic embryos as well as segments of seedlings or emblings origin and recently also explants taken from adult trees have been used.

Immature zygotic embryos: the zygotic embryos in this developmental stage are of extremely small size and usually are enclosed in megagametophytes. The megagametophyte tissue protects the embryo from undesirable environmental factors e.g. as dessiccation and it is supposed it also serves as a nutritive tissue for immature embryo. According to visual observation, the embryogenic tissue has been extruded from micropylar end of the megagametophyte (Fig. 2a). Using megagametophytes with immature embryos as explants is advantageous owing to the 
easy manipulation. However, immature embryos are available only in a very short period of the year. Immature embryos enclosed in megagametophytes have been used as explants in several conifer species as Abies alba (Gajdošová et al. 1995; Krajňáková et al. 2013a),

Abies nordmanniana (Nörgaard and Krogstrup 1991), Juniperus communis (Helmersson and von Arnold 2009), Taxus brevifolia and T. cuspidata (Ewald et al. 1995) but are typical for the species of the genus Pinus, as Pinus sylvestris (Aronen et al. 2009), Pinus radiata (Montalbán et al. 2012; Hargreaves et al. 2009), Pinus pinaster (Humanez et al. 2012), Pinus nigra (Salajova and Salaj 1992), Pinus palustris (Jones and van Staden 1995), Pinus halepensis (Montalbán et al. 2013) Pinus oocarpa (Lara-Chavez et al. 2011). Immature zygotic embryos excised from megagametophytes have been used in Picea glauca and Picea mariana (Hakman and Fowke 1987), Picea abies (Nagmani et al. 1987), Picea sitchensis (Krogstrup et al.1988).

The initiation frequencies have been variable depending on the species, year of cones harvest, developmental stage of zygotic embryos, nutrient medium composition reaching values in average $20 \%$ for Pinus pinaster (Humanez et al. 2012), 5-50\% for Juniperus communis (Helmersson and von Arnold 2009), 5\% for Pinus taeda (Becwar et al. 1990), 2.1-10.3\% for Pinus nigra Salaj et al. (2014) and $20.6 \%$ for Pinus radiata (Montalbán et al. 2012).

Mature zygotic embryos: for in vitro cultivation the mature zygotic embryos are excised from surface sterilised seeds and placed on culture medium. Their advantage as explants is that the seeds can be stored for longer time period, even for several years. The disadvatage of using of mature zygotic embryos has the risk of microbial contamination during the manipulation of the initial explant. The mature embryos as explants have been used for Picea abies (Hazubska-Przybyl and Bojarczuk 2008), Abies alba (Zoglauer and Rheuter 1996), Abies fraseri (Guevin and Kirby 1997), Abies hybrids (Korecky and Vitamvas 2011) and it has been less sucessful for Pinus species.

Seedlings explants: the cultivation of immature or mature zygotic embryos resulted in initiation of embryogenic tissue in numerous species of conifers, although in this case the genotyp of explants was unproven. Efforts have been made to extend the „initiation window" to explants in more advanced developmental stage. For this purpose mostly segments dissected from seedlings or emblings have been cultured.

In Picea abies embryogenic tissues have been initiated on cotyledon explants from 7-day-old seedlings (Lelu et al. 1987). Similarly, success in initiation from cotyledons has been achieved in Picea glauca, Picea mariana (Attree et al. 1990) and Abies hybrids
(Salajová and Salaj 2001). In some of these studies informations related to somatic embryo origin on structural level have been obtained (Lelu et al. 1987; Salajová and Salaj 2001).

Explants from adult trees: success has been achieved in Larix decidua, Larix eurolepis (Bonga 1997). In these experiments embryogenic tissues have been obtained on explants from adult 42-years old trees. In initiated tissues early somatic embryos were formed but finally, the regeneration of somatic seedlings failed. In subsequent experiments, optimisation of nutrient medium led to higher initiation frequencies but complete plantlet regeneration remained the bottleneck of the process (Bonga 2004). Park et al. (2010) obtained embryogenic tissue from shoot bud cultures of Pinus contorta and Klimaszewska et al. (2011) obtained it from primordial shoot explants from 10-years-old Picea glauca somatic trees. In these studies putative embryogenesis specific genes were analysed and attempts were made to select some genes as a markers of SE.

\section{Proliferation of embryogenic tissues}

After successful initiation the embryogenic tissues are maintained by regular transfers to fresh media in 2-3 weeks intervals. The maintenance media usually have the same or similar composition as the media used for initiation and this composition is sufficient for most of species. Sometimes, the medium composition needs minor changes and the content of plant growth regulators and/or the inorganic componets are reduced. The embryogenic tissues of conifer species share the same or very similar features. They are of white color, mucilaginous consistence and relatively fast growing tissues. The characteristic feature of tissues is the presence of bipolar somatic embryos (Fig. 2b) although the specific structural organisation is cell line dependent. The media used for maintenance of embryogenic tissues can be solid (solidified with agar or other gelling agent as Phytagel, gelrite) or liquid - suspension cultures. The suspension cultures are established by resuspension of a defined amount of tissues growing on solid medium in liquid and maintained by regular changes of liquid in 7-10 days intervals (Silveira et al. 2003; Vágner et al. 2005; Salaj et al. 2007)

\section{Maturation of somatic embryos}

According to von Arnold and Hakman (1988) somatic embryo development can be classified in four different stages: stage 1 - embryos composed of small, densely cytoplasmic cells subtended by a sus- 
pensor comprised of long, highly vacuolised cells, stage 2 - embryos (precotyledonary) with a more prominent and dense meristematic region, the embryos are still attached to tissues by long suspensor, stage 3 - embryos with cotyledons (Fig. 2c), stage 4 - green plantlets (Fig. 2d). The regenerated plantles are designated as emblings (somatic seedlings). On the culture media with plant growth regulators $(2,4-\mathrm{D}$, cytokinins) the somatic embryos are in the stage 1 . Their further development and maturation can be stimuated by transfer to medium lacking the mentioned PGRs and containing abscisic acid (ABA). The somatic embryo maturation is a complex developmental process characterised by internal histodifferentiation as well as morphological changes, the most apparent of them is appearance of cotyledons. The maturation is regulated by several factors; one of the most important is the genotype and therefore the maturation process is cell line dependent (Krajnaková et al. 2009; Alvarez et al. 2013; Fischerová et al. 2008; Montalbán et al. 2010; Vondráková et al. 2014). Another important factor is the medium composition used for maturation. ABA incorporated into the maturation medium stimulated storage material accumulation, synchronisation of somatic embryo development and prevents precoccious germination. The optimum ABA concentration used for somatic embryo maturation is different for each species and is defined empirically. In comparison to 2,4-D or cytokinins, the ABA concentration in nutrient media is higher reaching $32 \mu \mathrm{M}$ to $120 \mu \mathrm{M}$.

The osmotic potential of culture medium is another important factor to take into account. For many species polyethylene glycol (PEG-4000) was the best osmoticum (Svobodová et al. 1999; Vooková et al. 2010; Mauelová and Vitámvas 2007). The adverse effect of PEG has also been demonstrated in Picea abies (Bozkhov and von Arnold 1998). Somatic embryo maturation is also stimulated by high concentration of gellan gum $(1 \%)$ in the presence of ABA (Klimaszewska et al. 2000).

There exist considerable variations in mature somatic embryo yield/production among species and cell lines and maturation treatments. Some examples of mature somatic embryo yield (number) calculated per $1 \mathrm{~g}$ of fresh weight: 64 for Abies fraseri (Kim et al. 2009), 36 for Abies cephalonica (Krajňáková et al. 2009), 187 in Pinus pinaster (Alvarez et al. 2013), 321 in Pinus sylvestris (Aronen et al. 2009), 269 for Picea glauca (Kong and Yeung 1995), 65 for Picea mariana (Tremblay and Tremblay 1995), 300-960 for hybrid of Larix (Lelu et al. 1994). An undesirable phenomenon - loss of ability to produce mature somatic embryos - has been observed in embryogenic tissues of many species (Klimaszewska et al. 2009). This phenomenon can be avoid - at least partially - by cryopreservation and subsequent thawing of tissues.
The structural and morphological changes during maturation are accompained by biochemical changes as accumulation of storage reserves (Brownfield et al. 2007; Grigova et al. 2007; Kubes et al. 2014) in the form of protein and lipid bodies and the transport of protein bodies is mediated by Golgi apparatus (Hakman 1993). The storage proteins can also be markers of somatic embryo development (Teyssier et al. 2014).

\section{Germination of somatic embryos}

The germination of somatic embryos occurs on media without plant growth regulators and low content of carbohydrates. The success of germination process is also affected by several factors such as the environmental conditions in the previous maturation stage (Salaj et al. 2004; Krajňáková et al. 2008). Another factor involved is the genotype. In this sense, it was found, despite of the same maturation conditions, somatic embryos of different cell lines germinate by different frequencies (Lara-Chavez et al. 2011). The germination usually occurs in dark and after obtaining the small plants, they are transferred to light conditions. For germination low frequency light intensity is also recommended (Lara-Chavez et al. 2011). Improved germination of somatic embryos can be achieved by partial desiccation of somatic embryos immediately before germination (Vooková and Kormuták 2002; Grigová et al. 2007).

Successful germination and somatic seedling regeneration as well as establishment in soil (Fig. 2e, f) have been reported for a number of conifer species as Abies alba, Abies nordmanniana, Picea abies, Picea glauca, Picea mariana, Pinus caribaea, Pinus sylvestris, Pinus nigra, Pinus strobus, etc. (see reviews Attree and Fowke 1993; Klimaszewska and Cyr 2002; Krajňáková et al. 2013b).

Grossnickle (1999) followed the growth and physiological parameters (photosynthesis, water relations, frost tolerance) of Picea glauca engelmannii emblings and compared these parameters to seedlings developed from zygotic embryos. During nursery development and field performance, all the mentioned parameters of emblings were comparable to zygotic seedlings. These observations indicate the emblings meet all the criteria required for use in plantation forestry. Cyr and Klimaszewska (2002) referred the numbers of somatic seedlings produced for commercial purposes as follows: Picea glauca engelmannii 1 million (1999), Picea sitchensis 50000 (1998), Picea glauca 1.45 million (2000), Pinus taeda 0.2 million (2000-2001), Pseudotsuga menziesii 3.2 millions (2001). Grossnickle and Pait (2008) reported production of 10 million emblings (CellFor) and 500000 to 1 million emblings of Pinus taeda (Arborgen). 


\section{Conclusion}

SE in conifers represents an efficient in vitro regeneration system available for the study of early plant development and micropropagation as well as plays an important role in biotechnological approaches as genetic transformation and cryopreservation. The conifer species are recalcitrant to in vitro cultivation in general and also for SE but optimisation of plant growth regulators concentrations and combination in culture media as well as proper timing of pimary explant collection led to improvement of SE initiation. Successful emblings regeneration has been achieved in numerous conifer species and the regenerated plants have also been transferred to soil.

The work was supported by the Slovak Grant Agency VEGA, project number 2/0136/14. This work was co-funded by European Community under project no 26220220180: Building Research Centre „AgroBioTech".

\section{References}

Alvarez J.M., Bueno N., Cortizo M., Ordas R.J. 2013. Improving plantlet yield in Pinus pinaster somatic embryogenesis. Scandinavian Journal of Forest Research 28: 613-620.

Aronen T., Pehkonen T., Ryynanen L. 2009. Enhancement of somatic embryogenesis from immature zygotic embryos of Pinus sylvestris. Scandinavian Journal of Forest Research 24: 372-383.

Attree S.M., Budimir S., Fowke L.C. 1990. Somatic embryogenesis and plantlet regeneration from cultured shoots and cotyledons of seedlings from stored seeds of black and white sprees (Picea mariana and Picea glauca). Canadian Journal of Botany 68: 30-34.

Attree S.M., Fowke L.C. 1993. Embryogeny of gymnosperms: advances in synthetic seed technology of conifers. Plant Cell Tissue and Organ Culture 35: 1-35.

Becwar M.R., Nagmani R., Wann S.R. 1990. Initiation of embryogenic cultures and somatic embryo development in loblolly pine (Pinus taeda). Canadian Journal of Forest Research 20: 810-817.

Bonga J.M. 1997. The effect of collection date and frozen storage on the formation of embryo-like structures and elongating shoots from explants from mature Larix decidua and L. $x$ eurolepis. Plant Cell Tissue and Organ Culture 51: 195-200.

Bonga J.M. 2004. The effect of various culture media on the formation of embryo-like structures in cultures derived from explants taken from mature Larix decidua. Plant Cell Tissue and Organ Culture 77: 43-48.
Bozkhov P.V., von Arnold S. 1998. Polyethylene glycol promotes maturation but inhibits further development of Picea abies somatic embryos. Physiologia Plantarum 104: 211-224.

Brownfield D.L., Todd C.D., Stone S., Deyholos M.K., Gifford D.J. 2007. Patterns of storage protein and triacylglycerol accumulation during loblolly pine somatic embryo maturation. Plant Cell Tissue and Organ Culture 88: 217-223.

Cyr D.R., Klimaszewska K. 2002. Conifer somatic embryogenesis: II. Applications. Dendrobiology 48: 41-49.

Chalupa V. 1985. Somatic embryogenesis and plantlet regeneration from cultured immature and mature embryos of Picea abies (L.) Karst. Communicationes Instituti Forestalis Czechosloveniae 14: 57-63.

Durzan D.J., Chalupa V. 1976. Growth and metabolism of cells and tissue of jack pine (Pinus banksiana). 3. Growth of cells in liquid suspension cultures in light and darkness. Canadian Journal of Botany 54: 456-467.

Ewald D., Weckwereth W., Naujoks, G., Zocher R. 1995. Formation of embryo-like structures in tissue cultures of different Yew species. Journal of Plant Physiology 147: 139-143.

Fischerová L., Fischer L., Vondráková Z., Vagner M. 2008. Expression of the gene encoding transcription factor PaVP1 differs in Picea abies embryogenic lines depending on their ability to develop somatic embryos. Plant Cell Reports 27: 435-441.

Gajdošová A., Vooková B., Kormutak A., Libiakova G., Dolezel J. 1995. Induction, protein composition and DNA ploidy level of embryogenic calli of silver fir and its hybrids. Biologia Plantarum 37: 169-176.

Grigova M., Kubes M., Drazna N., Rezanka T., Lipavska H. 2007. Storage lipid dynamics in somatic embryos of Norway spruce (Picea abies): histochemical and quantitative analyses. Tree Physiology 27: 1533-1540.

Grossnickle S.C. 1999. Performance of conifer stock produced through somatic embryogenesis. In: Somatic Embryogenesis in Woody Plants. Jain S.M., Gupta P.K., Newton R.J. (eds.). Vol. 4, Kluwer Academic Publishers, Dordrecht, pp. 97-123.

Grossnickle S.C., Pait J. 2008. Somatic Embryo Tissue Culture for Applying Varietal Forestry to Conifer Species. USDA Forest Service Proceedings RMRS-P-57: 135-139.

Guevin T.G., Kirby E.G. 1997. Induction of embryogenesis in cultured mature zygotic embryos of Abies fraseri (Pursh) Poir. Plant Cell Tissue and Organ Culture 49: 219-222.

Hakman I., Fowke L.C., von Arnold S., Eriksson T. 1985. The development of somatic embryos in tissue cultures initiated from immature embryos 
of Picea abies (Norway spruce). Plant Science 38: 53-59.

Hakman I., Fowke L.C. 1987. Somatic embryogenesis in Picea glauca (white spruce) and Picea mariana (black spruce). Canadian Journal of Botany 65: 656-659.

Hakman I. 1993. Embryology in Norway spruce (Picea abies). Immunochemical studies on transport of a seed storage protein. Physiologia Plantarum 88: 427-433.

Hargreaves C.L., Reeves C.B., Find J.I., Gough K., Josekutty P., Skudder D.B., van der Maas S.A., Sigley M.R., Menzies M.I., Low C.B., Mullin T.J. 2009. Improving initiation, genotype capture, and family representation in somatic embryogenesis of Pinus radiata by a combination of zygotic embryo maturity, media and explant preparation. Canadian Journal of Forest Research 39: 1566-1574.

Hazubska-Przybyl T., Bojarczuk K. 2008. Somatic embryogenesis of selected spruce species (Picea abies, P. omorica, P. pungens "Glauca“ and P. breweriana). Acta Societatis Botanicorum Poloniae 77: 189-199.

Helmersson A., von Arnold S. 2009. Embryogenic cell lines of Juniperus communis: easy establishment and embryo maturation, limited germination. Plant Cell Tissue and Organ Culture 96: 211-217.

Humanez A., Blasco M., Brisa C., Segura J., Arrilaga I. 2012. Somatic embryogenesis from different tissues of Spanish population of maritime pine. Plant Cell Tissue and Organ Culture 111: 373383.

Jones N.B., van Staden J. 1995. Plantlet production from somatic embryos of Pinus patula. Journal of Plant Physiology 145: 519-525.

Kim Y.W., Newton R., Frampton J., Han K.-H. 2009. Embryogenic tissue initiation and somatic embryogenesis in Fraser fir (Abies fraseri (Pursh) Poir.). In Vitro Cellular and Developmental Biology Plant 45: 400-406.

Klimaszewska K., Cyr D.R. 2002. Conifer somatic embryogenesis: I. Development. Dendrobiology 48: 31-39.

Klimaszewska K., Bernier-Cardou M., Cyr D.R., Sutton B.C.S. 2000. Influence of gelling agents on culture medium gel strength, water availability, tissue water potential, and maturation response in embryogenic cultures of Pinus strobus. In Vitro Cellular and Developmental Biology-Plant 36: 279-286.

Klimaszewska K., Noceda C., Pelletier G., Label P., Rodriguez R., Lelu-Walter M.-A. 2009. Biological characterization of young and aged embryogenic cultures of Pinus pinaster (Ait.). In Vitro Cellular and Developmental Biology - Plant 45: 20-33.

Klimaszewska K., Overton C., Steward D., Rutledge R.G. 2011. Initiation of somatic embryos and re- generation of plants from primordial shoots of 10-year-old somatic white spruce and expression profiles of 11 genes followed during the tissue culture process. Planta 233: 635-647.

Kong L.S., Yeung E.C. 1995. Effects of silver nitrate and polyethylene glycol on white spruce (Picea glauca) somatic embryo development: enhancing cotyledonary embryo formation and endogenous ABA content. Physiologia Plantarum 93: 298-304.

Korecky J., Vitámvas J. 2011. Somatic embryogenesis in the hybrid Abies cilicica x Abies cephalonica. Journal of Forest Science 57: 401-408.

Krajňáková J., Gömöry D., Häggman H. 2008. Somatic embryogenesis in Greek fir. Canadian Journal of Forest Research 38: 760-769.

Krajňáková J., Häggman H., Gömöry D. 2009. Effect of sucrose concentration, polyethylene glycol and activated charcoal on maturation and regeneration of Abies cephalonica somatic embryos. Plant Cell Tissue and Organ Culture 96: 251-262.

Krajňáková J., Bertolini A., Gomory D., Vianello A., Häggman H. 2013a. Initiation, long-term cryopreservation and recovery of Abies alba Mill.embryogenic cell lines. In Vitro Cellular and Developmental Biology-Plant 49: 560-571.

Krajňáková J., Häggman H., Petrussa E., Bertolini A., Vianello A., Havel L. 2013b. Somatic Embryogenesis of Conifers. Fundamental Methods. Mendel University in Brno, pp. 58.

Krogstrup P., Eriksen E.N., Moeller J.D., Roulund H. 1988. Somatic embryogenesis in Sitka spruce (Picea sitchensis (Bong) Carr.). Plant Cell Reports 7: 594-597.

Kubes M., Drazna N., Konradova H., Lipavska H. 2014. Robust carbohydrate dynamics based on sucrose resynthesis in developing Norway spruce somatic embryos at variable sugar supply. In Vitro Cellular and Developmental Biology-Plant 50: 45-57.

Lara-Chavez A., Flinn B.S., Egertsdotter U. 2011. Initiation of somatic embryogenesis from immature zygotic embryos of Oocarpa pine (Pinus oocarpa Schiede ex Schlechtendal). Tree Physiology 31: 539-554.

Lelu M.-A., Boulay M., Arnaud Y. 1987. Obtention de cals embryogènes a partir de cotyledons de $P i$ cea abies (L.) Karst. prélevés sur de jeunes plantes agées de 3 à 7 jours après germination. Comptes Rendus de l'Academie des Sciences 305: 105-109.

Lelu M.A., Klimaszewska K., Charest P.J. 1994. Somatic embryogenesis from immature and mature zygotic embryos and from cotyledons and needles of somatic plantlets of Larix. Canadian Journal of Forest Research 24: 100-106.

Lelu-Walter M.-A., Thompson D., Harvengt L.,Sanchez L.,Toribio M., Paques L.E. 2013. Somatic embryogenesis in forestry with a focus on Europe 
state-of-the-art benefits, challenges and future direction. Tree Genetics and Genomes 9: 883-899.

Mauelová M., Vitamvas J. 2007. Differential success of somatic embryogenesis in random gene pool of Norway spruce. Journal of Forest Science 53: 74-87.

Montalbán I.A., De Diego N., Moncalean P. 2010. Bottlenecks in Pinus radiata somatic embryogenesis: improving maturation and germination. Trees-Structure and Function 24: 1061-1071.

Montalbán I.A., De Diego N., Moncalean P. 2012. Enhancing initiation and proliferation in radiata pine (Pinus radiata D. Don) somatic embryogenesis through seed family screening, zygotic embryo staging and media adjustments. Acta Physiologiae Plantarum 34: 451-460.

Montalbán I.A., Setine-Ollara A., Hargreaves C.L., Moncalean P. 2013. Somatic embryogenesis in Pinus halepensis Mill.: an important ecological species from Mediterranean forest. Trees-Structure and Function 27: 1339-1351.

Nagmani R., Becwar M.R., Wann S.R. 1987. Single-cell origin and development of somatic embryos in Picea abies (L.) Karst. (Norway spruce) and Picea glauca (Moench)Voss (white spruce). Plant Cell Reports 6: 157-159.

Nörgaard J.V., Krogstrup P. 1991. Cytokinin induced somatic embryogenesis from immature embryos of Abies nordmanniana. Lk. Plant Cell Reports 9: 509-5013.

Park S.Y., Klimaszewska K., Park J.Y., Mansfield S.D. 2010. Lodgepole pine: the first evidence of seed based somatic embryogenesis and the expression of embryogenesis marker genes in shoot bud cultures of adult trees. Tree Physiology 30: 14691478.

Salajová T., Salaj J. 1992. Somatic embryogenesis in European black pine (Pinus nigra Arn.). Biologia Plantarum 34: 213-218.

Salaj T., Ostrolucká M.G. 2010. Techniky in vitro a ich využitie pri lesných drevinách. In: Využitie inovatívnych vedeckých prístupov na zvýšenie efektívnosti lesného hospodárstva. Kormuták A. (ed.). ÚGBR SAV, Nitra, pp. 33-50.

Salajova T., Salaj J. 2001. Somatic embryogenesis and plantlet regeneration from cotyledon explants isolated from emblings and seedlings of hybrid firs. Journal of Plant Physiology 158: 747-755.

Salaj T., Matúšová R., Salaj J. 2004. The effect of carbohydrates and polyethylene glycol on somatic embryo maturation in hybrid fir Abies alba x A. numidica. Acta Biologica Cracoviensia, Series Botanica 46: 159-167.

Salaj T., Blehová B., Salaj J. 2007. Embryogenic suspension cultures of Pinus nigra Arn.: growth pa- rameters and maturation ability. Acta Physiologiae Plantarum 29: 225-231.

Salaj T., Fraterova L., Carach M., Salaj J. 2014. The effect of culture medium formulation on Pinus nigra somatic embryogenesis. Dendrobiology 71: 119-128.

Silveira V., Floh E.I.S., Handro V., Guerra M.P. 2003. Effect of plant growth regulators on the cellular growth and levels of intracellular protein, starch and polyamines in embryogenic suspension cultures of Pinus taeda. Plant Cell Tissue and Organ Culture 76: 53-60.

Svobodová H., Albrechtova J., Kumstyrova L., Lipavska H., Vagner M., Vondráková Z. 1999. Somatic embryogenesis in Norway spruce: Anatomical study of embryo development and influence of polyethylene glycol on maturation process. Plant Physiology and Biochemistry 37: 209-221.

Tautorus T.E., Fowke L.C., Dunstan D.I. 1991. Somatic embryogenesis in conifers. Canadian Journal of Botany 69: 1873-1899.

Teyssier C., Maury S., Beaufor M., Grondin C., Delaunay A., LeMette C., Ader K., Cadene M., Label P., Lelu-Walter M.-A. 2014. In search of markers for somatic embryo maturation in hybrid larch (Larix x eurolepis): global DNA methylation and proteomic analysis. Physiologia Plantarum 150: 271-291.

Tremblay L., Tremblay F.M 1995. Maturation of black spruce somatic embryos: Sucrose hydrolysis and resulting osmotic pressure of the medium. Plant Cell Tissue and Organ Culture 42: 39-46.

Vágner M., Vondráková Z., Fischerová L., Opatrná J. 2005. Norway spruce somatic embryogenesis: membrane rafts as a compromise between liquid and solidified media. In: Liquid Culture System for in vitro Plant Propagation. Hvoslef Eide A.K., Preil W. (eds.). Springer, Dordrecht, pp. 295-302. Vooková B., Kormuták A. 2002. Some features of somatic embryo maturation in Algerian fir. In Vitro Cellular and Developmental Biology-Plant 38: 549-551.

Vookova B., Machava J., Salgovicova A., Kormutak A. 2010. Optimization of Algerian fir somatic embryos maturation. Biologia Plantarum 54: 177-180.

von Arnold S., Hakman I. 1988. Regulation of somatic embryo development in Picea abies by abscisic acid. Journal of Plant Physiology 132: 164-169.

Vondráková Z., Eliášová K., Vágner M. 2014. The anti-actin drugs latrunculin and cytochalasin affect the maturation of spruce somatic embryos in different way. Plant Science 221: 90-99.

Zoglauer K., Reuther G. 1996. Somatische Embryogenese bei der Weistanne (Abies alba Mill.) Mitteilungen der Landesanstalt für Wald- und Forstwirtschaft 11: 123-135. 